\title{
Analisis Optimasi Untuk Prioritas Pembangunan Embung Berbasis Ketersediaan Air Di Kecamatan Kedungadem Kabupaten Bojonegoro
}

\section{Optimization Analysis on Reservoir Building Priority Based on Water Availability in Kedungadem Regency, Bojonegoro District}

\author{
Yulia Indriani ${ }^{1}$, Lily Montarcih Limantara $^{1}$, Widandi Soetopo $\left.^{1 *}\right)$ \\ ${ }^{1}$ Jurusan Teknik Pengairan, Fakultas Teknik, Universitas Brawijaya, Malang, Indonesia
}

\section{Article info:}

Kata kunci:

alokasi dana, dinamik stokastik, embung, optimasi

Keywords:

budget allocation, optimization, reservoir, stochastic dynamics

Article history:

Received: $30-03-2020$

Accepted: 27-11-2020

${ }^{*}$ Koresponden email: lialio.link@gmail.com

\begin{abstract}
Abstrak
Kecamatan Kedungadem berada di Kabupaten Bojonegoro yang pada setiap tahunnya mengalami kekeringan. Diperlukan program peningkatan kapasitas embung secara bertahap. Untuk menentukan alokasi anggaran dana, dilakukan pemilihan tiga embung prioritas. Penelitian ini ditujukan untuk dasar penentuan pemilihan lokasi embung. Pemilihan embung prioritas menggunakan analisa manfaat keuntungan terbesar dengan berbasis ketersediaan air. Dari analisa manfaat keuntungan diperoleh prioritas pembangunan embung meliputi Embung Panjang, Embung Kepohkidul Dusun Pedang dan Embung Sidomulyo. Optimasi dilakukan dengan alokasi anggaran dana pada embung tersebut, agar menghasilkan keuntungan untuk irigasi. Dengan menggunakan metode dinamik stokastik, apabila kebijakan alokasi anggaran dana diterapkan, akan menghasilkan keuntungan yang jauh lebih besar apabila anggaran dibagi rata untuk ketiga embung tersebut. Jika dilakukan sesuai dengan perhitungan optimasi, nilai benefit cost ratio yang diperoleh sebesar 1.71. Akan tetapi apabila tidak diterapkan optimasi, benefit cost ratio yang diperoleh sebesar 0.67 .
\end{abstract}

\section{Abstract}

Kedungadem District is in Bojonegoro Regency, which experiences drought every year. A gradual capacity building program is needed. To determine the budget allocation for funds, three priority reservoirs were selected. The purpose of this research is to determine a basis for selecting reservoirs location. Selection of priority reservoirs uses the largest benefit analysis on a water basis, based on benefits analysis of reservoirs development priority including Panjang reservoir, Kepohkidul Dusun Sword and Sidomulyo reservoirs. Optimization is carried out by allocating budget funds to these reservoirs to gain profit for irrigation. By using the dynamic stochastic method, if the budget allocation policy of funds is implemented, it will result in a much greater profit if the budget is divided equally for the three reservoirs. If done in accordance with optimization calculations, the value of benefit cost ratio obtained is 1.71. However, if optimization is not applied, the benefit cost ratio will be 0.67 .

Kutipan: Indriani, Y., Limantara, L. M., \& Soetopo, W. (2020). Analisis Optimasi Untuk Prioritas Pembangunan Embung Berbasis Ketersediaan Air Di Kecamatan Kedungadem Kabupaten Bojonegoro. Jurnal Teknik Pengairan. https://doi.org/10.21776/ub.pengairan.2020.011.02.03 


\section{Pendahuluan}

Kabupaten Bojonegoro merupakan kabupaten yang setiap tahunnya mengalami krisis air. Untuk mengatasi masalah tersebut, pemerintah Kabupaten Bojonegoro memiliki program yang dinamakan "Program Seribu Embung" hal ini tercantum dalam lampiran RPJMD Kabupaten Bojonegoro tahun 2018-2023. Program seribu embung ini bukanlah program dengan pembangunan embung sejumlah seribu, melainkan pembangunan embung yang cukup banyak, dan menyebar di seluruh wilayah Kabupaten Bojonegoro.

Embung-embung di Kabupaten Bojonegoro berfungsi untuk menampung air hujan dan digunakan suatu kelompok masyarakat desa, atau embung didefinisikan sebagai konservasi air berbentuk kolam untuk menampung air hujan dan air limpasan (run off) serta sumber air lainnya yang dimanfaatkan untuk pemenuhan kebutuhan air irigasi. Namun, pembangunan embung di Kabupaten Bojonegoro tersebut masih kurang maksimal. Banyak daerah-daerah yang masih mengalami kekurangan air pada setiap tahunnya. Salah satu wilayah yang selalu mengalami kekeringan adalah Kecamatan Kedungadem. Hal ini dikarenakan, pembangunan embung tidak berdasarkan alokasi penganggaran yang tepat, melainkan hanya berdasar permintaan masing-masing desa.

Kelemahan lain dari pengelolaan dana yang tidak tepat, adalah penurunan dana hanya pada area irigasi berbasis luas tanpa memperhitungkan karakteristik masing-masing area irigasi. Untuk mengatasi masalah tersebut diperlukan perencanaan pembangunan embung secara optimal dengan cara pembagian alokasi dana yang efektif dan efisien dengan memanfaatkan ketersediaan air yang ada pada embung-embung sehingga menghasilkan keuntungan yang optimal. Berdasarkan hasil inventarisasi Dinas PU SDA (2018) Kabupaten Bojonegoro terdapat 89 embung perlu normalisasi, enam embung perlu normalisasi dan rehabilitasi bangunan inflow dan outflow, 47 embung perlu normalisasi dan perluasan, 52 embung perlu perluasan, sembilan embung perlu perbaikan tanggul.

Dari 52 embung di Kabupaten Bojonegoro yang memerlukan perluasan, terdapat tujuh embung di Kecamatan Kedungadem. Embung - embung tersebut adalah Embung Megale 3, Embung Panjang 1, Embung Kepohkidul Dusun Pedang, Embung Geger 3, Embung Drokilo 3, Embung Sidomulyo 3, dan Embung Kedungadem. Perluasan embung di Kecamatan Kedungadem dilakukan secara bertahap, menyesuaikan anggaran dana yang ada. Untuk menentukan alokasi anggaran dana, akan dilakukan pemilihan tiga embung prioritas.

Studi ini akan menerapkan optimasi alokasi penganggaran dana dengan cara mensimulasikan ketersediaan embung-embung berdasarkan tiga embung terpilih di Kecamatan Kedungadem sehingga diperoleh alternatif-alternatif pola pembagian dana untuk mencapai keuntungan yang optimal. Dikarenakan inflow utama dari embung tersebut merupakan hujan dengan sifatnya yang tak tentu (stokastik) maka proses dalam analisis pengerjaan studi ini dengan menggunakan metode dinamik stokastik. Metode dinamik stokastik memperhitungkan probabilitas setiap kejadian hujan. Sehingga analisis optimasi dapat mendekati kebenaran. Sehingga hasil optimasi mendekati kebenaran.

Tujuan dari penelitian ini adalah untuk menentukan dasar pemilihan lokasi embung serta pengaruh dinamik stokastik terhadap distribusi anggaran dana.

\section{Bahan dan Metode}

\subsection{Lokasi studi}

Studi penelitian adalah Kecamatan Kedungadem Kabupaten Bojonegoro. Kedungadem adalah sebuah kecamatan di Kabupaten Bojonegoro, Provinsi Jawa Timur. Di Kecamatan Kedungadem terdapat 79 embung tadah hujan yang dimanfaatkan untuk Irigasi maupun air baku.

\subsection{Model dinamik stokastik}

Menurut Paul J.O. (1984) analisis sistem adalah suatu metode untuk mempelajari dan menganalisa berbagai aspek dari suatu sistem. Analisa sistem sumber daya air bertujuan untuk memodifikasi ketersediaan air secara alami. Menurut Cooper, Leon dan Mary W. (1981) dengan menggunakan metode analisis sistem, diharapkan air yang tersedia secara alami tersebut dan pengoperasiannya yang belum dilakukan secara optimal, dapat menjadi ketersediaan air yang dapat 
diandalkan dan didistribusikan secara optimal. Menurut John A.D dan Warren A.H. (1970) sistem adalah sekumpulan komponen yang fungsional dan saling berkaitan dengan berbagai cara. Sistem tersebut memerlukan input dan menghasilkan output.

Banyak penelitian terkait program dinamik stokastik. Sebagai contoh, Stedinger et al. (1984) mengembangkan model program dinamik stokastik untuk menentukan kebijakan operasi waduk. Karamouz dan Vasiliadis (1992) menggunakan teori keputusan bayesian untuk mengembangkan program dinamik stokastik pada analisa optimasi waduk. Loaiciga dan Marino (1986) memperkenalkan interaksi antara nilai yang diharapkan dan varians dari fungsi tujuan sebagai cara untuk menganalisa risiko yang menolak sifat pengambilan keputusan dalam operasi inervervoir. Yeh (1985) dan Simonovic (1992) memberikan tinjauan literatur yang luas dan evaluasi berbagai model yang digunakan dalam manajemen dan operasi waduk. Beberapa studi menerapkan optimasi stokastik untuk memeriksa kinerja atau untuk menentukan kebijakan operasional dari sistem yang ada. Beberapa kendala reliabilitas dimasukkan untuk mengevaluasi operasi sistem yang ada atau untuk menentukan aturan operasi heuristik berdasarkan pada pendekatan deterministik.

\subsection{Sasaran}

Sifat ketidakpastian atau stokastik diperhitungkan dalam optimasi dengan memasukkan sebaran probabilitas inflow pada setiap tahap optimasi. Dengan memperhitungkan sifat stokastik inflow tersebut, maka sasaran optimasi operasi waduk dapat ditentukan, misalnya memaksimalkan produksi listrik tahunan yang diharapkan. Kata "diharapkan" dipakai untuk mencerminkan adanya harapan terhadap sesuatu yang tidak pasti, hal inilah yang merupakan ciri teknik program dinamik stokastik. Secara sistematis, sasaran tersebut dapat dinyatakan dalam fungsi sasaran (objective function) (Shrestha 1987).

\subsection{Kinerja sistem (system performance)}

Persamaan tidak tetap dalam artian dapat berubah apakah menggunakan deviasi release atau deviasi tampungan saja, bergantung pada bagian mana penekanannya (Loucks 1984).

\subsection{Program dinamik stokastik tipe no. 1}

Penyelesaian program dinamik stokastik Tipe No. 1 pada dasarnya adalah dengan mentransformasikan proses stokastik menjadi proses deterministik. Hal ini dilakukan dengan menghitung tabel Expected Value (EV) pada Tabel 1 yang berisi nilai-nilai akibat tahap (stage return) sebagai fungsi dari tabel Expected Value ini, untuk masalah program dinamik dengan $\mathrm{n}$ tahap dan variabel keputusan dengan kisaran x1 sampai dengan xm.

Tabel 1. Bentuk tabel expected value

\begin{tabular}{ccccccc}
\hline & \multicolumn{5}{c}{ Nilai alokasi tahap untuk variabel keputusan xj } \\
\hline & X1 & X2 & X3 & X4 & X5 & Xm \\
\hline Fungsi Tahap-1(x) & F1(x1) & F1(x2) & F1(x3) & F1(x4) & F1(x5) & F1(xm) \\
\hline Fungsi Tahap-2(x) & F2(x1) & F2(x2) & F2(x3) & F2(x4) & F2(x5) & F2(xm) \\
\hline Fungsi Tahap-3(x) & F3(x1) & F3(x2) & F3(x3) & F3(x4) & F3(x5) & F3(xm) \\
\hline Fungsi Tahap-n(x) & Fn(x1) & Fn(x2) & Fn(x3) & Fn(x4) & Fn(x5) & Fn(xm) \\
\hline
\end{tabular}

Jadi Fi(xj) adalah nilai akibat tahap ke-i untuk pengambilan keputusan sebesar xj, maka untuk menghitung setiap nilai Fi(xj) digunakan konsep Expected Value. Apabila semua Fi(xj) pada tabel Expected Value telah selesai dihitung dengan benar, maka nilai-nilai akibat tahap ini dapat dianggap deterministik. Selanjutnya dengan menggunakan tabel expected value tersebut, perhitungan optimasi dengan prosedur recursive dapat dilakukan seperti pada program dinamik deterministik (Limantara and Soetopo 2011).

\subsection{Pengumpulan data}

Data-data yang diperlukan dalam studi ini meliputi data sekunder terkait dengan analisis optimasi distribusi air irigasi: 
1. Peta topografi

2. Data hujan harian

3. Data lokasi embung

4. Volume tampungan embung

5. Anggaran untuk peningkatan kapasitas embung

6. Areal irigasi

7. Data klimatologi Stasiun Klimatologi Padangan

\subsection{Pengolahan data}

Prosedur penyelesaian untuk permasalahan optimasi alokasi penganggaran dana dengan program dinamik pada Kecamatan Kedungadem Kabupaten Bojonegoro dilakukan sebagai berikut:

1. Menghitung sebaran probabilitas inflow masing-masing embung

2. Menghitung rencana anggaran biaya untuk embung eksisting

3. Menghitung rencana anggaran biaya untuk peningkatan kapasitas embung

4. Menghitung volume inflow embung

5. Menghitung volume evaporasi embung

6. Menghitung volume embung berdasarkan inflow dan outflow

7. Menghitung luas areal yang dapat diairi embung

8. Menghitung keuntungan yang diperoleh dari peningkatan kapasitas embung

9. Membuat tabel EV (Expected Value) yang memuat unsur-unsur:

a. Anggaran dana (tersedia) untuk dialokasikan

b. Kapasitas tampungan embung perluasan berdasarkan alokasi dana (setelah anggaran tersedia dialokasikan).

c. Inflow embung berdasarkan sebaran probabilitas

d. Kehilangan air akibat evaporasi

e. Volume ketersediaan air total

f. Kebutuhan air tanaman jagung

g. Luas areal maksimal yang dapat terairi

h. Keuntungan produksi pertanian

i. Keuntungan produksi pertanian dikalikan dengan sebaran probabilitas

10.Hasil dari tahap pertama ditransformasikan ke tahap berikutnya, demikian sampai akhir.

11.Keuntungan maksimum pada tahap terakhir merupakan kebijakan total secara keseluruhan Untuk Diagram Alir Penelitian disajikan pada Gambar 1.

\section{Hasil dan Pembahasan}

\subsection{Pemilihan embung prioritas}

Di Kecamatan Kedungadem Kabupaten Bojonegoro terdapat 79 embung tadah hujan. Untuk menentukan prioritas embung untuk peningkatan kapasitas, terlebih dahulu dihitung keuntungan yang paling maksimal dari 79 embung yang terdapat di Kecamatan Kedungadem. Berdasarkan prioritas manfaat luas areal yang dapat terairi, untuk selanjutnya analisa penganggaran dana dilakukan pada tiga embung. Meliputi Embung Panjang 1, Embung Kepohkidul Dusun Pedang dan Embung Sidomulyo 3.

\subsection{Pengaruh stasiun hujan}

Volume ketersediaan air embung dihitung berdasarkan hujan dan aliran permukaan. Untuk mengetahui pengaruh stasiun hujan yang mengisi embung dilakukan analisa peta poligon thiessen.

\subsection{Analisa hidrologi}

Analisa inflow embung dihitung berdasarkan hujan yang jatuh pada embung. Untuk mengetahui ketersediaan data dapat digunakan atau tidak, dilakukan uji lengkung massa ganda, uji RAPS dan uji outlier. 


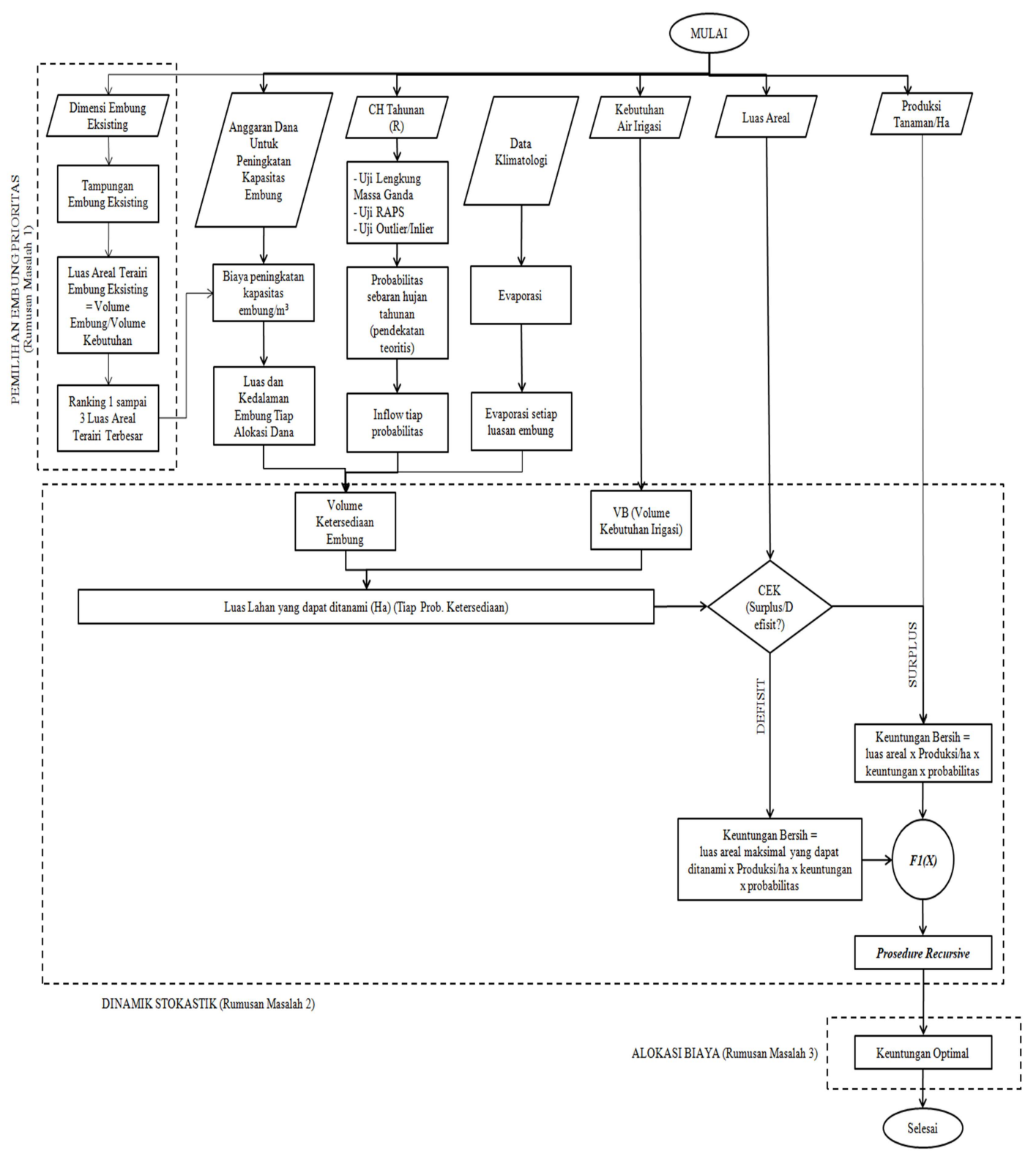

Gambar 1. Diagram alir penelitian

\subsection{Sebaran probabilitas}

Distribusi normal disebut juga "Gaussian distribution" adalah salah satu distribusi kemungkinan teoritis dengan variabel random sinambungan. Distribusi ini berbeda dengan distribusi poisson dan binomial yang bervariabel diskrit acak (Dajan 1986). Suatu peubah acak kontinyu X yang distribusinya berbentuk lonceng. Persamaan matematika distribusi peluang peubah normal kontinyu bergantung pada dua parameter $\mu$ dan $\sigma$ yaitu rataan dan simpangan bakunya. Jadi fungsi pada $\mathrm{X}$ akan dinyatakan dengan $\mathrm{n}(\mathrm{x} ; \mu, \sigma)$, Walpole (2012:173). Maka:

$$
\mathrm{f}(\mathrm{x} ; \mu, \sigma)=\frac{1}{\sqrt{2 \pi \sigma}} e^{-\frac{1}{2 \sigma^{2}}(x-\mu)^{2}} \frac{1}{\sqrt{2 \pi \sigma}} e^{-\frac{1}{2 \sigma^{2}}(x-\mu)^{2}}
$$


Dalam penelitian ini, data sebaran probabilitas diperoleh dari pendekatan sebaran teoritis, dikarenakan data yang tersedia sangat sedikit. Data yang digunakan merupakan data hujan tahunan pada stasiun hujan PJ. Kedungadem, Stasiun Hujan Simorejo, Stasiun Hujan Cawak dan Stasiun Hujan Mekuris. Sebaran probabilitas hujan tahunan ditunjukkan oleh Gambar 2.

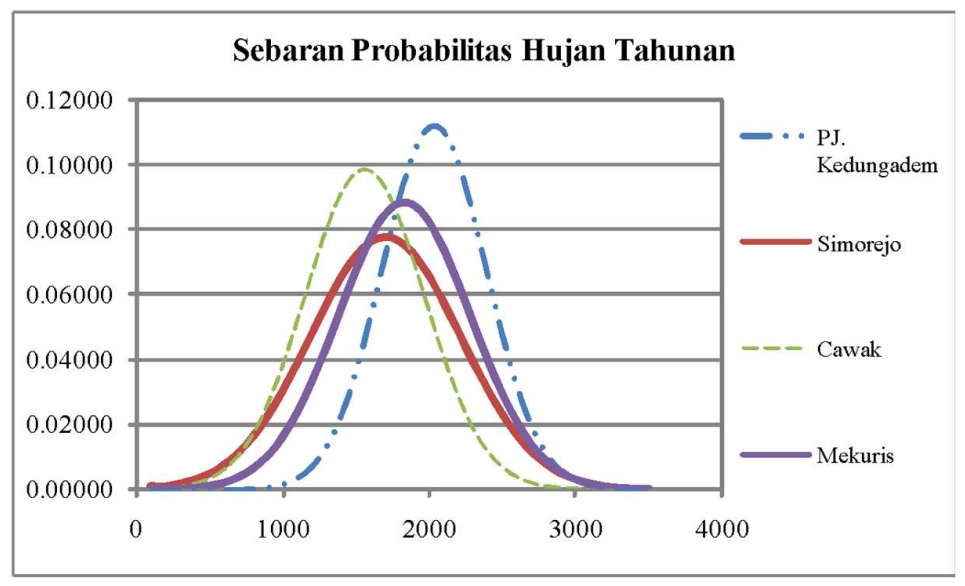

Gambar 2. Sebaran probabilitas hujan tahunan

\subsection{Evaporasi}

Dalam penelitian ini, data klimatologi digunakan untuk menganalisa besaran evaporasi pada embung. Perhitungan evaporasi menggunakan metode penmann modifikasi. Evaporasi ini dipertimbangkan sebagai outflow embung, sehingga mempengaruhi volume ketersediaan air embung.

Berdasarkan analisa sebaran hujan tahunan pada lokasi studi, dapat terlihat bahwa rata-rata hujan tahunan tertinggi berada pada stasiun hujan PJ. Kedungadem. Dan rata-rata hujan tahunan terendah Stasiun Hujan Simorejo. Sehingga, untuk lokasi-lokasi embung yang berada pada pengaruh stasiun hujan PJ. Kedungadem berpotensi memiliki ketersediaan air yang lebih menguntungkan apabila dibandingkan dengan embung-embung yang berada pada pengaruh stasiun hujan lainnya.

\subsection{Rencana anggaran biaya}

Anggaran biaya dihitung dengan mempertimbangkan beberapa faktor penting antara lain harga satuan pekerjaan digunakan harga satuan yang dikeluarkan oleh bagian pembangunan Pemerintah Kabupaten Bojonegoro pada tahun 2020 nomor 188/312/KEP/412.11/2019, analisa yang dipergunakan adalah analisa harga satuan yang dikeluarkan oleh kementerian pekerjaan umum pada tahun 2016, serta dikenakan nilai PPN sebesar 10\%.

Perhitungan Expected Value dihitung dengan alokasi dana Rp 840,000,000, dengan grid Rp 40,000,000. Sehingga untuk mengetahui keuntungan masing-masing kelipatan grid $\mathrm{Rp} \mathrm{40,000,000}$ diperlukan analisa biaya peningkatan kapasitas embung dengan setiap anggaran kelipatan $\mathrm{Rp}$ 40,000,000. Pada Tabel 2 disajikan contoh perhitungan biaya untuk alokasi dana $\mathrm{Rp} 600,000,000$.

\subsection{Optimasi alokasi dana untuk peningkatan kapasitas embung}

Dalam penelitian ini, sistem tahapan program dinamik menggunakan metode forward recursive, yaitu dimulai dari tahapan awal bergerak menuju tahap akhir. Tahapan tersebut dimulai dari Embung Panjang 1 - Embung Kepohkidul Dusun Pedang - Embung Sidomulyo 3. Setelah optimasi dilakukan dengan forward recursive pada tahap selanjutnya dilakukan pelacakan balik dengan backtracking.

Dari alokasi dana untuk peningkatan kapasitas embung sebesar Rp 840,000,000 akan didistribusikan untuk embung-embung di Kecamatan Kedungadem. Berdasarkan pemilihan embung prioritas yang didiskusikan sebelumnya, embung yang menjadi prioritas adalah Embung Panjang 1, Embung Kepohkidul Dusun Pedang dan Embung Sidomulyo 3. Sehingga untuk selanjutnya, alokasi 
dana akan didistribusikan ke tiga lokasi embung tersebut. Dalam penelitian ini akan digunakan metode dinamik stokastik tipe no. 1 untuk memperoleh nilai keuntungan optimal dari alokasi distribusi dana.

Tabel 2. Perhitungan rencana anggaran biaya Embung Panjang 1 untuk alokasi dana Rp 600.000.000

\begin{tabular}{|c|c|c|c|c|c|}
\hline No. & Uraian & Satuan & Volume & $\begin{array}{l}\text { Harga } \\
\text { Satuan }\end{array}$ & Total Harga \\
\hline 1 & Mobilisasi dan demobilisasi peralatan & Ls & 1 & $5,000,000$ & $5,000,000$ \\
\hline 2 & $\begin{array}{l}\text { Galian biasa (menggunakan alat) dan } \\
\text { pembuangan dari lokasi sejauh } 5 \mathrm{~km}\end{array}$ & $\mathrm{~m}^{3}$ & 2,830 & 46,790 & $132,413,170$ \\
\hline 3 & Geo membran HDPE halus $0.75 \mathrm{~mm}$ & $\mathrm{~m}^{2}$ & 8,730 & 46,740 & $408,030,446$ \\
\hline A & Total biaya rehabilitasi embung & & & & $545,455,175$ \\
\hline B & $\begin{array}{l}\text { Pajak pertambahan nilai }(\mathrm{ppn})=10 \% \mathrm{x} \\
\text { (a) }\end{array}$ & & & & $54,545,517$ \\
\hline \multirow{2}{*}{$\mathrm{C}$} & Jumlah total harga $=(\mathrm{A})+(\mathrm{B})$ & & & & $600,000,692$ \\
\hline & Dibulatkan & & & & $600,000,000$ \\
\hline \multicolumn{6}{|c|}{ Terbilang : Enam Ratus Juta Rupiah } \\
\hline
\end{tabular}

Penerapan optimasi dalam program dinamik pada penelitian ini meliputi beberapa dasar perhitungan, antara lain:

1. Optimasi dilakukan pada tiga embung prioritas, yaitu Embung Panjang 1, Embung Kepohkidul Dusun Pedang dan Embung Sidomulyo 3. Dengan areal Embung Panjang 4 ha, Embung Kepohkidul Dusun Pedang 4 ha dan Embung Sidomulyo 3 sebesar 4 ha. Ketiga embung ini, digunakan untuk mengairi pada musim tanam ketiga dengan tanaman palawija.

2. Jika dana yang diberikan untuk masing-masing embung yang dikaji sudah mampu mengairi luas maksimal yang ada, maka untuk pengalokasian dana selebihnya akan menghasilkan keuntungan yang sama dengan yang dihasilkan untuk luas areal yang ada.

3. State variable merupakan anggaran dana yang tersedia, yaitu $R p 840,000,000$ dengan grid $R p$ $40,000,000$.

4. Hasil optimasi yaitu keuntungan bersih dari luas lahan yang dapat diairi untuk tanaman jagung.

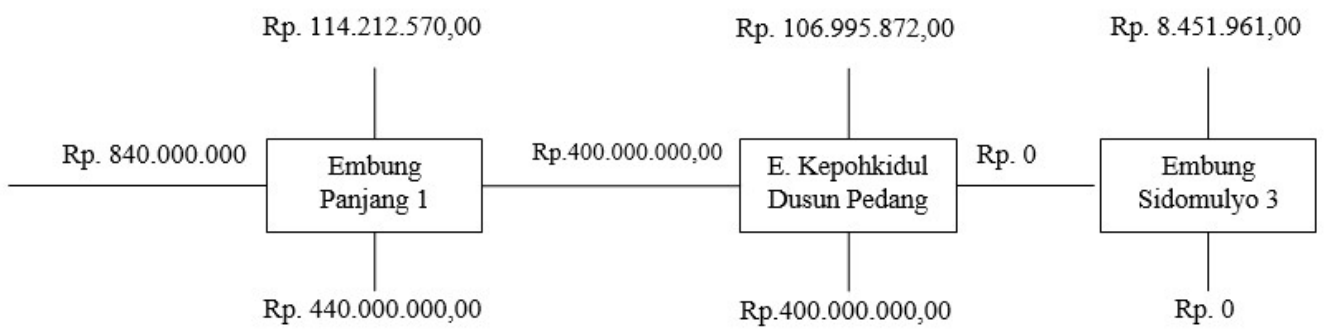

Gambar 3. Sistem tahapan program dinamik Embung Panjang 1, Embung Kepohkidul Dusun Pedang dan Embung Sidomulyo 3 untuk alokasi dana Rp 840,000,000.

Gambar 3 menunjukkan bahwa dana yang tersedia adalah Rp840,000,000. Kemudian dana tersebut dialokasikan untuk peningkatan kapasitas Embung Panjang 1 sebesar Rp 440,000,000 dan menghasilkan keuntungan $\mathrm{Rp}$ 114,212,570. Sisa dana Rp 400,000,000 dialokasikan untuk peningkatan kapasitas Embung Kepohkidul Dusun Pedang dan menghasilkan keuntungan Rp 106,995,872, sehingga Embung Sidomulyo 3 tidak memperoleh penjatahan dana dan keuntungan yang dihasilkan Rp 8,451,961. 


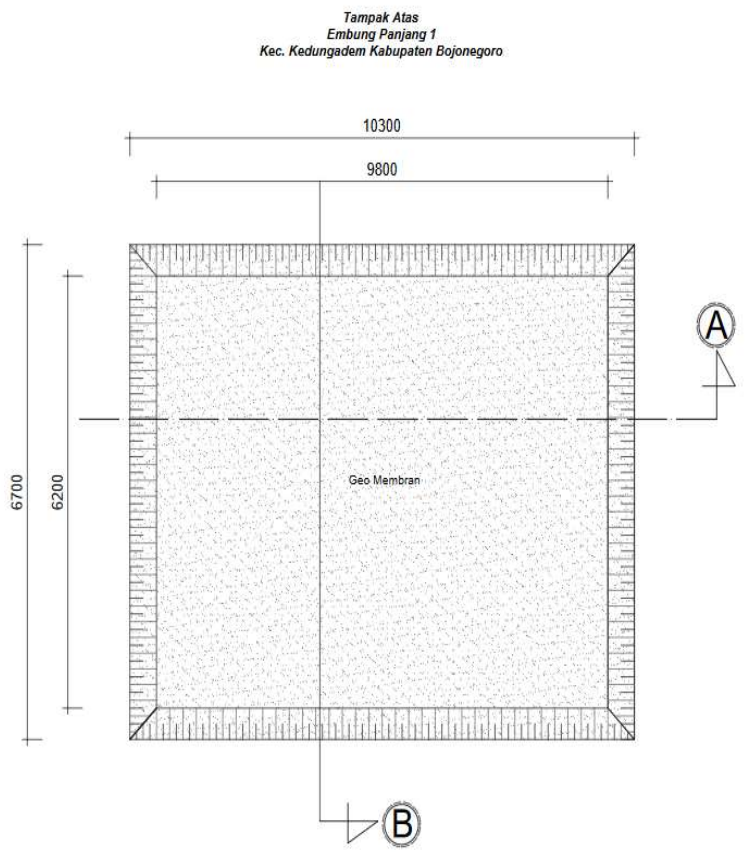

Gambar 4. Tampak atas Embung Panjang 1 Kecamatan Kedungadem Kabupaten Bojonegoro

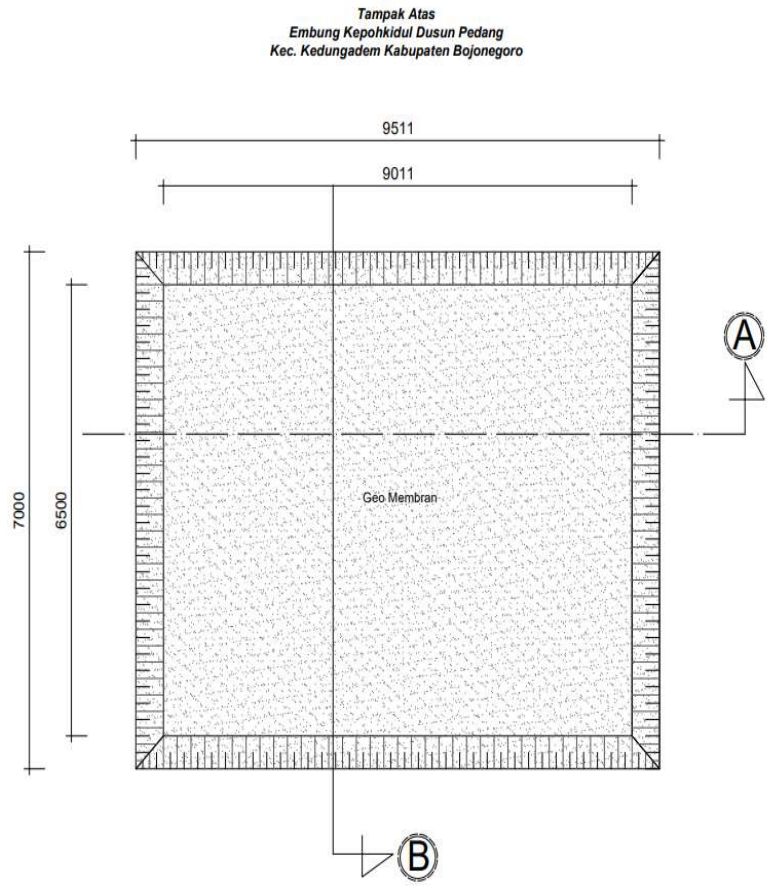

Gambar 5. Tampak atas Embung Kepohkidul Dusun Pedang Kecamatan Kedungadem Kabupaten Bojonegoro

\subsection{Desain embung}

Berdasarkan hasil optimal yang telah dilakukan pada sub bab sebelumnya anggaran dana yang tersedia digunakan untuk peningkatan kapasitas Embung Panjang dan Embung Kepohkidul Dusun 
Pedang, dengan masing-masing anggaran untuk Embung Panjang sebesar Rp 400,000,000 dan Embung Kepohkidul Dusun Pedang Rp 440,000,000.

\section{Kesimpulan}

Dasar pemilihan lokasi embung untuk lokasi studi ditentukan berdasarkan keuntungan paling maksimum yang diperoleh. Dalam hal ini yaitu areal terairi terluas ke 1, 2 dan 3. Berdasarkan perhitungan yang telah dilakukan, bahwa urutan areal terluas, yaitu Embung Panjang 1, Embung Kepohkidul Dusun Pedang, kemudian Embung Sidomulyo 3. Embung Panjang 1 mempunyai volume 20,100 $\mathrm{m}^{3}$, dengan dimensi lebar $67 \mathrm{~m}$, panjang $100 \mathrm{~m}$ dan tinggi $3 \mathrm{~m}$. Embung Kepohkidul Dusun Pedang mempunyai volume $19,950 \mathrm{~m}^{3}$, dengan dimensi lebar $70 \mathrm{~m}$, panjang $95 \mathrm{~m}$ dan tinggi $3 \mathrm{~m}$. Embung Sidomulyo 3 mempunyai volume 17,775 $\mathrm{m}^{3}$, dengan dimensi lebar $75 \mathrm{~m}$, panjang $79 \mathrm{~m}$ dan tinggi $3 \mathrm{~m}$. Ketiga embung ini digunakan untuk mengairi sawah dengan tanaman jagung pada musim kemarau. Jika diasumsikan volume ketersediaan air penuh (sama dengan volume embung), maka luas maksimal yang dapat diairi:

a. Embung Panjang 1 mampu mengairi 2.61 ha.

b. Embung Kepohkidul Dusun Pedang mampu mengairi sawah seluas 2.59 ha.

c. Embung Sidomulyo 3 mampu mengairi sawah seluas 2.31 ha.

Model program dinamik stokastik untuk pemilihan prioritas pembangunan embung pada studi ini memperhatikan beberapa aspek, meliputi: inflow embung, evaporasi, luas areal yang mampu terairi embung. Kondisi stokastik berupa hujan tahunan yang menjadi inflow embung. Berdasarkan analisa, Embung Sidomulyo 3 mempunyai keuntungan paling kecil dibandingkan Embung Panjang 1 dan Embung Kepohkidul Dusun Pedang. Hal ini disebabkan probabilitas curah hujan di Embung Sidomulyo 3 lebih kecil dibanding dua embung lainnya. Untuk memperoleh keuntungan maksimum, pembangunan embung sebaiknya memperhatikan kondisi ketersediaan air yang ada.

Stasiun Hujan Kedungadem mempunyai rata-rata hujan tahunan 2,000 mm mempunyai probabilitas 0.11125 sedangkan pada Stasiun Hujan Simorejo pada hujan tahunan 2,000 mm mempunyai probabilitas 0.06587. Sehingga keuntungan yang diperoleh pada Embung Panjang 1 dan Embung Kepohkidul Dusun Pedang akan lebih besar daripada Embung Sidomulyo 3.

Dengan memperhatikan sifat acak hujan akan menghasilkan analisa yang lebih mendekati kebenaran, dikarenakan semua peluang kejadian dihitung. Berdasarkan analisa optimasi yang telah dilakukan, untuk memperoleh keuntungan paling maksimum, alokasi biaya untuk perluasan kapasitas Embung Panjang 1 sebesar Rp 440,000,000 menghasilkan manfaat sebesar Rp 114,212,570. Alokasi dana untuk perluasan kapasitas Embung Kepohkidul Dusun Pedang sebesar Rp 400,000,00 menghasilkan keuntungan Rp 106,995,872. Sedangkan untuk Embung Sidomulyo 3 tidak ada penjatahan dana untuk peningkatan kapasitas embung. Dengan tidak ada penjatahan anggaran, Embung Sidomulyo 3 menghasilkan keuntungan Rp 8,451,961.

Dengan menerapkan kebijakan tersebut keuntungan yang akan diperoleh sebesar $\mathrm{Rp}$ 229,660,404. Apabila kebijakan alokasi anggaran dana ini diterapkan, akan menghasilkan keuntungan yang jauh lebih besar apabila anggaran dibagi rata untuk ketiga embung tersebut. Jika dilakukan sesuai dengan perhitungan optimasi, nilai benefit cost ratio yang diperoleh sebesar 1.71. Akan tetapi apabila tidak diterapkan optimasi, benefit cost ratio yang diperoleh sebesar 0.67.

\section{Daftar Pustaka}

Badan Perencanaan Daerah Kabupaten Bojonegoro. 2018-2023. Lampiran Jurnal Rencana Pembangunan Jangka Menengah Daerah, Bojonegoro.

Cooper, Leon, Mary, W.1981. Introduction to Dynamic Programming. USA: Pergamon Press.

Dinas Pekerjaan Umum Sumber Daya Air Kabupaten Bojonegoro. 2018. Buku Saku Pengelolaan Embung dan Manual OP dalam Program Seribu Embung 2013-2018, DPUSDA Bojonegoro.

Dajan, Anto. 1986. Pengantar Metode Statistik Jilid II. Jakarta : LP3ES .

John, A.D., Warren, A.H. 1970. Water Resources System Engineering. USA: McGraw Hill.

Karamouz, M., Houck, M. H., and Delleur, J. W. 1992. "Bayesian stochastic optimization of reservoir operation using uncertain forecasts. "Water Resour Res., 28(5), 1221 - 1232 
Limantara, Lily M. \& Soetopo, Widandi. 2011. Manajemen Sumber Daya Air. Bandung: CV. Lubuk Agung.

Loaiciga, H. A., and Marino, M. A. 1986. "Risk analysis for Reservoir Operation." Water Resour. Res., 22(4), 483-488.

Loucks, Daniel P. dkk., 1984, Stochastic Dynamic Programming Model of Reservoir Operation Optimization, Water Resource Research, Vol. 20, No. 11, pp. 1499-1505

Paul, J.O.1984. System Analysis for Civil Engineering.Durham-New Hampshire: University of New Hampshire.

Sheresta, D.L, 1987, Optimum Hydropower System Configuration Considering Operational Aspects, Master Thesis, AIT, Bangkok

Simonovic, S. P. 1992. "Reservoir System Analysis: Closing gap Between Theory and Practice.” J. Water Resor. Plan. Manage., 118(3), 262-280

Stedinger, J. R., Sule, B. F., and Louck, D. P. 1984. "Stochastic Dynamic Programming Models for Reservoir Operation Optimization." Water Resour. Res., 20(11), 1499-1505.

Walpole, Ronald E. 1995. Pengantar Statistik Edisi Ke-4. Jakarta: PT Gramedia

Yeh, W. W. G. 1985. "Reservoir Management and Operation Models: A State-of-the-art review. "Water Resour. Res., 21(12), 1797-1818 